\title{
GENETIC EFFECT OF MIGRATORY COMPOUNDS FROM BOTTLED NATURAL DRINKING WATER STORED UNDER DIRECT SUNLIGHT
}

\author{
Fahim $^{1}$ H.M., Neima, K. Alsonosy ${ }^{2}$, Khallaf ${ }^{1}$ M.F., Abdeldaim ${ }^{1}$ Y.A. \\ and Hemat E. Elsheshetawy ${ }^{1}$
}

1- Food Sci. Dept., Fac. of Agric., Ain Shams Univ., P.O. Box 68, Hadayek Shoubra, 11241, Cairo, Egypt

2- Genetic Dept., Fac. of Agric., Ain Shams Univ., P.O. Box 68, Hadayek Shoubra, 11241, Cairo, Egypt

Keywords: Polyethylene terephthalate (PET) bottles; bottled water; Sunlight; Phthalates; Migration; Toxicity; Carcinogenic; Genotoxic effects

\section{ABSTRACT}

The drinking water is one of the important routes for human exposure to contaminants through releasing of antimony $(\mathrm{Sb})$ and polymers from polyethylene terephthalate (PET) plastic. The aim of this study was to investigate the effect of sunlight on chemical compounds migration into PET-bottled water and studying the cytotoxicity of di-butyl phthalate (DBP) and di-octyl phthalate (DOP) by SMART in Drosophila melanogaster. Four random water bottle samples produced by various companies as: A (PET, clear, 0.6L), B (PET, clear, 1.5L), C (PET, blue, 1.5L) and D (polycarbonate $\mathrm{PC}$, blue, 19L) for studying the effect of direct sunlight exposure on migration of antimony and phthalates. Experiment was carried out in the presence of sunlight ( $7 \mathrm{~h}$ daily) for 210 day. The migrated compounds profile $(\mu \mathrm{g} / \mathrm{L})$ that detected sample $(A)$ before storage were only two compounds formaldehyde (FA) and acetaldehyde (AA) out of nine compounds. During storage under sunlight, four compounds (Sb), bis-phenol A (BPA), dimethyl phthalate (DMP) and diethyl phthalate (DEP) were increased till 30th day then did not affect till the end of storage. Other detected compounds were continuously progressed till the end of storage with different rates. The highest rate was appeared in case of FA, it was 222 fold followed by DOP compound ( 173 fold) as well as DBP (75.3 fold) and finally the AA compound with 17.9 fold. Regarding to another sample $B$, only 3 compounds (BPA, DMP and DBP) were not detected at zero time. The AA compound was detected with the highest concentration $(0.9 \mu \mathrm{g} / \mathrm{L})$ and the lowest one was DOP $(0.007 \mu \mathrm{g} / \mathrm{L})$. Only four compounds were detected before storage named $\mathrm{Sb}, \mathrm{DOP}, \mathrm{FA}$ and $\mathrm{AA}$, the lowest level $(0.006 \mu \mathrm{g} / \mathrm{L})$ was noticed in DOP, while the moderate level was recorded in FA $(0.03 \mu \mathrm{g} / \mathrm{L})$ and $\mathrm{Sb}(0.08 \mu \mathrm{g} / \mathrm{L})$. Other detected compounds; i.e. DBP, DOP, AA and FA were consequently increased with higher levels. This study investigated genotoxic effects of (DBP) and (DOP) at $30 \mu \mathrm{g} / \mathrm{ml}$ concentration using the somatic mutation and recombination test (SMART). The cytotoxicity of the tested phthalate compounds was also assessed at five different concentrations $0.5,1,5,10$ and $20 \mu \mathrm{g} / \mathrm{ml}$ in two types of human cell lines; liver cancer (HepG2), colon cancer (HCT-116) using neutral red cytotoxicity assay. All of tested compounds significantly showed high levels of tumor induction and frequency compared to the negative control in SMART assay. It was also reduced the viability of the HepG2 cell lines cells using different concentrations and the highest cytotoxic effect. While, on HCT-116 showed no cytotoxic effect.

\section{INTRODUCTION}

Bottled water is considered as an important source of clean water. Polyethylene terephthalate (PET) is the most popular material for food or beverage packaging (ILSI-Europe, 2000) and phthalate compounds are used as softeners and plasticizers in a wide range of plastic materials. PET bottles are occasionally exposed to direct sunlight due to mishandling in retail shops which 
causes leaching of some substances through thermo- mechanical process into the bottled water (Bach et al 2012). Antimony trioxide $\left(\mathrm{Sb}_{2} \mathrm{O}_{3}\right)$ is used as a catalyst in the manufacture of PET, so it can be leaching to water inside the bottle (Shotyk and Krachler, 2007). Formaldehyde, acetaldehyde, (BPA), (DMP), (DEP), (DBP), di (2ethylhexyl) phthalate (DEHP) and (DOP) can be released as harmful chemicals from PET bottles into water. Chemically, phthalates are not bound to products, for this reason, it can easily leak out to enter the environment and diffuse within the materials due to their lipophilic properties (Fujii et al 2003; Kavlock et al 2006). Dibutyl phthalate (DBP) can passes through the placental and blood (Huang et al 2014) and found in rat brain (Williams and Blanchfield, 1975). Dioctyl phthalate (DOP) changed lymphoid organs in male rats, affected on cell viability of lymph nodes and increased the size and number of lysosomes and golgi apparatus (Dogra et al 1985).

There has been a growing concern regarding a possible health hazard to humans by migrated compounds (Kleinsasser et al 2000). Rapid, inexpensive and sensitive Somatic Mutations and Recombination Test (SMART) in Drosophila melanogaster is used successfully to detect carcinogenic compounds (Nepomuceno, 2015). Induction of tumors in Drosophila instead of marker clones might be directly adverse the risk of these migrants for inducing cancer in humans (Sidorov et al 2001). The application of mammalian cell cultures cytotoxicity assays for quantitating the potencies of cytotoxin agents included either the MTT colorimetric cell viability assay (Borenfreund and Puerner 1984) or neutral red cell viability assay (NR) (Fotakis and Timbrell 2006). The NR assay has been found to be more sensitive than the MTT assay (Hansen et al 1989).

Drosophila imaginal discs in larvae, (which develop into adult organs; i.e. wings, eyes, legs ... etc), are considered to be good material for genetic study at somatic cell level using suitable marker(s) in heterozygous condition allows to detect the genetic damage induced in the somatic cell led to loss of heterozygosity ( $\mathrm{LOH}$ ) that appears as mosaic spot on the corresponding cell organ.

In SMART systems, the frequencies of induced mutations depend on the expression of marker genes in different organ with regard to the temporal distribution of cell divisions in different developmental stage of the fly. Most of tumor suppressor genes are recessive lethals, clones homozygous of each genes induced in heterozygous lar- vae manifest as tumors outgrowth in adult flies. However, both mutagen compounds were assayed using tumor mosaic spot test (wts) to evaluate and to compare the efficiency of these assays to detect potential genotoxicity hazards in Drosophila as a model system.

From the point of view that drinking water is one of the primary routes for human exposure to contaminants through releasing of $\mathrm{Sb}$ and polymers from PET plastic, the aim of this study was to investigate the effect of sunlight on chemical migration into PET-bottled water and studying the cytotoxicity of DBP and DOP by SMART in Drosophila melanogaster.

\section{MATERIALS AND METHODS}

Standards of the individual phthalate esters: (DMP), (DEP), (DBP), (DOP) were purchased from a World of Fine Chemicals (CDH). Bisphenol A was purchased from Alpha Chemika (Mumbai). All reagents were analytical grade and checked for contamination with phthalates before using. Mytomycin C (MMC: C15H18N4O5) manufactured by Bristol-Myers Squibb Caribbean Company Mayaguez, Puetro, USA was used. Drosophila stocks carries a recessive lethal wts3-17 allele with the genetic structure of $q$ st1 in1 Kni.ri-1 and ppwts317/TM3.sb1 and $\hat{\alpha}$ wild type were provided by Bloomington Drosophila Stock Centre of the University of Indiana, USA, under registry No. Bloomington/ 7052 (Lindsely and Zimm 1992).

Four random water bottle samples produced by various companies as: A (PET, clear, 0.6L), B ( PET, clear, 1.5L), C (PET, blue, 1.5L) and D (polycarbonate $\mathrm{PC}$, blue, $19 \mathrm{~L}$ ) were taken from a local market in Cairo, Egypt for studying the effect of direct sunlight exposure on migration of antimony and phthalates. Experiment was carried out in the presence of sunlight ( $7 \mathrm{~h}$ daily) for 210 days (Muhamad et al 2011). Control sample was protected from direct sunlight exposure by storing in a dark place at room temperature (22-25oC).

Total $\mathrm{Sb}$ concentration was detected using hydride generation atomic fluorescence spectrometry (Carneado et al 2015). Formaldehyde was determined by Spectrophotometer (DR 2000) (Matthews and Howell, 1981). Acetaldehyde analyzed on a high performance liquid chromatography (Azra et al 2012). (DMP), (DEP), (DBP), (DOP), N, NDiethylhydroxyl phthalate (DEHP) and (BPA) were determined by gas chromatograph (HPLC ultra, Flexar LC / Flexar FX-20, Perkin Elmer) as (Tienpont et al 2005). 

under direct sunlight

\section{Somatic mutation and recombination tests (SMART)}

The wts/TM3 females were crossed to wild type males. After 2 days the parental flies were removed and 56-68 hours old larvae were transferred to a standard Drosophila medium containing $20 \mu \mathrm{g} / \mathrm{ml}$ of an appropriate Mitomycin C (MMC) solution for 24 hours, then transferred to standard Drosophila medium. For (DBP) and (DOP) treatments; $30 \mu \mathrm{g} / \mathrm{ml}$ solution of (DBP) and (DOP) were mixed in $100 \mathrm{ml}$ of standard Drosophila medium at $50^{\circ} \mathrm{C}$. All Drosophila stocks and crosses were maintained at $25 \pm 3^{\circ} \mathrm{C}$. To score warts, a Leica stereomicroscope was used at a standard magnification of $25 \mathrm{X}$. Tumors were only included when large enough to be classified unambiguously.

X2 $2 \times 2$ test was used to evaluate the significant of difference between negative control and other treatments. The relative frequency was calculated as a frequency of induced tumors in treatments with DBP and DOP.

\section{Neutral red cytotoxicity assay}

Neutral red cytotoxicity assay based on the initial protocol described by Borenfreund and Puerner (1984) and modified by Fotakis and Timbrell (2006) was carried out. Cytotoxicity assay was measured as optical density at $540 \mathrm{~nm}$. Doseresponse curves were plotted, and $50 \%$ inhibitory concentrations of plant extracts (IC50) were calculated through Graph Pad Prism software program. For statistical analysis of data, multiple comparisons were performed using one-way analysis of variance (ANOVA) followed by the LSD test for post hoc analysis. Statistical significance was accepted at a level of $P<0.05$. Data were analyzed using SPSS (version 11; Chicago, IL, USA).

\section{RESULTS AND DISCUSSION}

\section{Migration compounds profile of bottled water stored under sunlight}

Data given in Table (1) indicated the migration compounds profile $\mu \mathrm{g} / \mathrm{L}$ that detected in water (sample A, PET clear and 0.6L) owing to storage under sunlight for 210 day. Before storage only two compounds ( $F A$ and $A A$ ) were detected out of nine compounds at $15^{\text {th }}$ day of storage all of nine compounds were detected with different concentra- tions. Both of $F A$ and $A A$ were greatly increased to be 4 and $5 \mu \mathrm{g} / \mathrm{L}$, respectively. Other seven detected compounds that disappeared in zero time were started to be detect, four of them were around $1 \mu \mathrm{g} / \mathrm{L}$ (Sb, DEHP, DEP and DBP), meanwhile DOP was $0.4 \mu \mathrm{g} / \mathrm{L}$, and DMP was $0.6 \mu \mathrm{g} / \mathrm{L}$.

During storage under sunlight four compounds (Sb, BPA, DMP and DEP) were increased till $30^{\text {th }}$ day then did not affect till the end of storage. Other detected compounds were continuously progressed till the end of storage with different rates. The highest rate was appeared in case of FA it was 222 fold followed by DOP compound (173 fold) as well as DBP (75.3 fold) and finally AA compound with 17.9 fold.

Regarding to another sample B that differed in size (1.5L), Table (2) indicated that only $3 \mathrm{com}$ pounds (BPA, DMP and DBP) were not detected at zero time. The $A A$ compound was detected with the highest concentration $(0.9 \mu \mathrm{g} / \mathrm{L})$ and the lowest one was DOP $(0.007 \mu \mathrm{g} / \mathrm{L})$. At $15^{\text {th }}$ day of storage BPA and DMP was started to be detect with 0.02 and $0.4 \mu \mathrm{g} / \mathrm{L}$ then increased at $30^{\text {th }}$ day and stop increasing till the end of storage. The third compound that detected at $15^{\text {th }}$ day (DBP) was $0.7 \mu \mathrm{g} / \mathrm{L}$ then sharply progressed to be $74.0 \mu \mathrm{g} / \mathrm{L}$ (about 106 fold).

Sb compound was increased till $30^{\text {th }}$ day then showed a constant level till the end of storage. Similar trend was recorded in case of DEHP but after $90^{\text {th }}$ day of exposure to sunlight. A continuous increase was recorded in other detected compounds (DEP, DOP, FA and AA).

Regarding the effect of bottle's color on migrated compounds concentration during storage under sunlight, Table (3) represented such effect in PET blue, 1.5L natural drinking water bottle. Only four compounds were detected before storage named $\mathrm{Sb}, \mathrm{DOP}, \mathrm{FA}$ and $\mathrm{AA}$, the lowest level $(0.006 \mu \mathrm{g} / \mathrm{L})$ was noticed in DOP, while the moderate level was recorded in FA $(0.03 \mu \mathrm{g} / \mathrm{L})$ and $\mathrm{Sb}$ $(0.08 \mu \mathrm{g} / \mathrm{L})$. The highest one $(0.4 \mu \mathrm{g} / \mathrm{L})$ was recorded in case of $A A$. It is of interest that two of detected compounds were constant after $30^{\text {th }}$ day till the end of storage (210 day), these compounds are Sb and DMP. Other detected compounds; i.e. DBP, DOP, AA and FA were consequently increased with higher levels that were $70.2,68.8,37.9$ and $24.10 \mu \mathrm{g} / \mathrm{L}$, respectively. On the other hand, three of detected migrated compounds were shown with moderate concentrations ranged between 1.5$5.2 \mu \mathrm{g} / \mathrm{L}$. These compounds are DEP, Sb and DEHP. 
Table 1. Migrated compounds concentration under sunlight $(\mu \mathrm{g} / \mathrm{L})$ for sample $A^{*}$

\begin{tabular}{|c|c|c|c|c|c|c|c|c|c|}
\hline $\begin{array}{c}\text { Storage } \\
\text { time (day) }\end{array}$ & Sb & FA & AA & BPA & DEHP & DMP & DEP & DBP & DOP \\
\hline Zero & $0.00^{\mathrm{C}}$ & $0.09^{\mathrm{D}}$ & $1.82^{\mathrm{D}}$ & $0.00^{\mathrm{C}}$ & $0.00^{\mathrm{D}}$ & $0.00^{\mathrm{C}}$ & $0.00^{\mathrm{C}}$ & $0.00^{\mathrm{E}}$ & $0.00^{\mathrm{E}}$ \\
$\mathbf{1 5}$ & $0.90^{\mathrm{B}}$ & $4.00^{\mathrm{C}}$ & $5.00^{\mathrm{C}}$ & $0.04^{\mathrm{B}}$ & $1.20^{\mathrm{C}}$ & $0.60^{\mathrm{B}}$ & $0.90^{\mathrm{B}}$ & $1.00^{\mathrm{D}}$ & $0.40^{\mathrm{D}}$ \\
$\mathbf{3 0}$ & $2.60^{\mathrm{A}}$ & $19.80^{\mathrm{B}}$ & $31.90^{\mathrm{B}}$ & $0.05^{\mathrm{A}}$ & $4.90^{\mathrm{B}}$ & $1.10^{\mathrm{A}}$ & $1.20^{\mathrm{A}}$ & $2.90^{\mathrm{C}}$ & $1.90^{\mathrm{C}}$ \\
$\mathbf{9 0}$ & $2.60^{\mathrm{A}}$ & $19.80^{\mathrm{B}}$ & $32.0^{\mathrm{B}}$ & $0.05^{\mathrm{A}}$ & $5.10^{\mathrm{A}}$ & $1.10^{\mathrm{A}}$ & $1.20^{\mathrm{A}}$ & $30.20^{\mathrm{B}}$ & $29.10^{\mathrm{B}}$ \\
$\mathbf{1 5 0}$ & $2.60^{\mathrm{A}}$ & $20.0^{\mathrm{A}}$ & $32.60^{\mathrm{A}}$ & $0.05^{\mathrm{A}}$ & $5.10^{\mathrm{A}}$ & $1.10^{\mathrm{A}}$ & $1.20^{\mathrm{A}}$ & $75.30^{\mathrm{A}}$ & $69.20^{\mathrm{A}}$ \\
$\mathbf{2 1 0}$ & $2.60^{\mathrm{A}}$ & $20.0^{\mathrm{A}}$ & $32.60^{\mathrm{A}}$ & $0.05^{\mathrm{A}}$ & $5.10^{\mathrm{A}}$ & $1.10^{\mathrm{A}}$ & $1.20^{\mathrm{A}}$ & $75.30^{\mathrm{A}}$ & $69.20^{\mathrm{A}}$ \\
\hline
\end{tabular}

Values followed by the same letter in a column are not significantly different $P \leq 0.05$

*See abstract and materials and methods

Table 2. Migration compounds concentration under sunlight $(\mu \mathrm{g} / \mathrm{L})$ for sample $B^{*}$

\begin{tabular}{|c|c|c|c|c|c|c|c|c|c|}
\hline $\begin{array}{c}\text { Storage } \\
\text { time/day }\end{array}$ & Sb & FA & AA & BPA & DEHP & DMP & DEP & DBP & DOP \\
\hline Zero & $0.02^{\mathrm{C}}$ & $0.06^{\mathrm{D}}$ & $0.90^{\mathrm{C}}$ & $0.00^{\mathrm{C}}$ & $0.10^{\mathrm{D}}$ & $0.00^{\mathrm{C}}$ & $0.03^{\mathrm{D}}$ & $0.00^{\mathrm{E}}$ & $0.007^{\mathrm{E}}$ \\
$\mathbf{1 5}$ & $0.60^{\mathrm{B}}$ & $2.00^{\mathrm{C}}$ & $4.00^{\mathrm{B}}$ & $0.02^{\mathrm{B}}$ & $1.10^{\mathrm{C}}$ & $0.40^{\mathrm{B}}$ & $0.70^{\mathrm{C}}$ & $0.70^{\mathrm{E}}$ & $0.50^{\mathrm{D}}$ \\
$\mathbf{3 0}$ & $2.10^{\mathrm{A}}$ & $17.0^{\mathrm{B}}$ & $31.90^{\mathrm{A}}$ & $0.04^{\mathrm{A}}$ & $4.30^{\mathrm{B}}$ & $1.00^{\mathrm{A}}$ & $1.10^{\mathrm{B}}$ & $2.50^{\mathrm{D}}$ & $1.60^{\mathrm{C}}$ \\
$\mathbf{9 0}$ & $2.10^{\mathrm{A}}$ & $17.0^{\mathrm{B}}$ & $32.0^{\mathrm{A}}$ & $0.04^{\mathrm{A}}$ & $4.40^{\mathrm{A}}$ & $1.00^{\mathrm{A}}$ & $1.10^{\mathrm{B}}$ & $33.70^{\mathrm{C}}$ & $31.60^{\mathrm{B}}$ \\
$\mathbf{1 5 0}$ & $2.10^{\mathrm{A}}$ & $17.30^{\mathrm{B}}$ & $32.0^{\mathrm{A}}$ & $0.04^{\mathrm{A}}$ & $4.40^{\mathrm{A}}$ & $1.00^{\mathrm{A}}$ & $1.20^{\mathrm{A}}$ & $72.00^{\mathrm{B}}$ & $66.00^{\mathrm{A}}$ \\
$\mathbf{2 1 0}$ & $2.10^{\mathrm{A}}$ & $18.0^{\mathrm{A}}$ & $32.40^{\mathrm{A}}$ & $0.04^{\mathrm{A}}$ & $4.40^{\mathrm{A}}$ & $1.00^{\mathrm{A}}$ & $1.20^{\mathrm{A}}$ & $74.0^{\mathrm{A}}$ & $66.90^{\mathrm{A}}$ \\
\hline
\end{tabular}

Values followed by the same letter in a column are not significantly different $\mathrm{P} \leq 0.05$

*See abstract and materials and methods

Table 3. Migrated compounds concentration under sunlight $(\mu \mathrm{g} / \mathrm{L})$ for sample $C^{*}$

\begin{tabular}{|c|c|c|c|c|c|c|c|c|c|}
\hline $\begin{array}{c}\text { Storage } \\
\text { time/day }\end{array}$ & Sb & FA & AA & BPA & DEHP & DMP & DEP & DBP & DOP \\
\hline Zero & $0.08^{\mathrm{D}}$ & $0.03^{\mathrm{D}}$ & $0.40^{\mathrm{E}}$ & $0.0^{\mathrm{C}}$ & $0.00^{\mathrm{D}}$ & $0.00^{\mathrm{C}}$ & $0.00^{\mathrm{D}}$ & $0.00^{\mathrm{E}}$ & $0.006^{\mathrm{E}}$ \\
$\mathbf{1 5}$ & $1.30^{\mathrm{C}}$ & $6.00^{\mathrm{C}}$ & $1.00^{\mathrm{D}}$ & $0.03^{\mathrm{B}}$ & $1.40^{\mathrm{C}}$ & $0.90^{\mathrm{B}}$ & $1.20^{\mathrm{C}}$ & $1.30^{\mathrm{D}}$ & $0.80^{\mathrm{D}}$ \\
$\mathbf{3 0}$ & $2.60^{\mathrm{B}}$ & $24.0^{\mathrm{B}}$ & $37.0^{\mathrm{C}}$ & $1.00^{\mathrm{A}}$ & $5.00^{\mathrm{B}}$ & $1.20^{\mathrm{A}}$ & $1.40^{\mathrm{B}}$ & $3.60^{\mathrm{C}}$ & $2.90^{\mathrm{C}}$ \\
$\mathbf{9 0}$ & $2.60^{\mathrm{B}}$ & $24.0^{\mathrm{B}}$ & $37.10^{\mathrm{B}}$ & $1.00^{\mathrm{A}}$ & $5.20^{\mathrm{A}}$ & $1.20^{\mathrm{A}}$ & $1.40^{\mathrm{B}}$ & $33.50^{\mathrm{B}}$ & $32.10^{\mathrm{B}}$ \\
$\mathbf{1 5 0}$ & $2.70^{\mathrm{A}}$ & $24.10^{\mathrm{A}}$ & $37.90^{\mathrm{A}}$ & $1.00^{\mathrm{A}}$ & $5.20^{\mathrm{A}}$ & $1.20^{\mathrm{A}}$ & $1.50^{\mathrm{A}}$ & $70.20^{\mathrm{A}}$ & $68.80^{\mathrm{A}}$ \\
$\mathbf{2 1 0}$ & $2.70^{\mathrm{A}}$ & $24.10^{\mathrm{A}}$ & $37.90^{\mathrm{A}}$ & $1.00^{\mathrm{A}}$ & $5.20^{\mathrm{A}}$ & $1.20^{\mathrm{A}}$ & $1.50^{\mathrm{A}}$ & $70.20^{\mathrm{A}}$ & $68.80^{\mathrm{A}}$ \\
\hline
\end{tabular}

Values followed by the same letter in a column are not significantly different $\mathrm{P} \leq 0.05$

*See abstract and materials and methods

When polycarbonate used as a colored bottle contained 19L, Table (4) showed absence of five compounds (DMP, DEP, DBP, DOP and FA) before storage. The DEHP and AA compounds came with the same concentration $0.2 \mu \mathrm{g} / \mathrm{L}$ at zero time storage. Similar trend that observed earlier (after $30^{\text {th }}$ day) was also recorded in case of DEHP, DMP, DEP and FA. On the other hand each of $\mathrm{Sb}$, BPA, DBP, DOP and AA were continuously increased with different rates till the end of exposure. The higher values were recorded for BPA 52.9 and AA $36.4 \mu \mathrm{g} / \mathrm{L})$. 

under direct sunlight

Table 4. Migrated compounds concentration under sunlight $(\mu \mathrm{g} / \mathrm{L})$ for sample $D^{*}$

\begin{tabular}{|c|c|c|c|c|c|c|c|c|c|}
\hline $\begin{array}{c}\text { Storage } \\
\text { time/day }\end{array}$ & Sb & FA & AA & BPA & DEHP & DMP & DEP & DBP & DOP \\
\hline Zero & $0.01^{\mathrm{D}}$ & $0.00^{\mathrm{D}}$ & $0.20^{\mathrm{E}}$ & $0.03^{\mathrm{E}}$ & $0.20^{\mathrm{D}}$ & $0.00^{\mathrm{C}}$ & $0.00^{\mathrm{D}}$ & $0.00^{\mathrm{E}}$ & $0.00^{\mathrm{E}}$ \\
$\mathbf{1 5}$ & $1.10^{\mathrm{C}}$ & $6.00^{\mathrm{C}}$ & $0.80^{\mathrm{D}}$ & $0.07^{\mathrm{D}}$ & $1.40^{\mathrm{C}}$ & $0.90^{\mathrm{B}}$ & $1.00^{\mathrm{C}}$ & $1.20^{\mathrm{D}}$ & $0.80^{\mathrm{D}}$ \\
$\mathbf{3 0}$ & $2.40^{\mathrm{B}}$ & $21.30^{\mathrm{A}}$ & $36.10^{\mathrm{C}}$ & $2.60^{\mathrm{C}}$ & $4.70^{\mathrm{B}}$ & $1.20^{\mathrm{A}}$ & $1.30^{\mathrm{B}}$ & $3.20^{\mathrm{C}}$ & $2.60^{\mathrm{C}}$ \\
$\mathbf{9 0}$ & $2.40^{\mathrm{B}}$ & $21.20^{\mathrm{B}}$ & $36.30^{\mathrm{B}}$ & $22.70^{\mathrm{B}}$ & $4.90^{\mathrm{A}}$ & $1.20^{\mathrm{A}}$ & $1.30^{\mathrm{B}}$ & $4.10^{\mathrm{B}}$ & $4.80^{\mathrm{B}}$ \\
$\mathbf{1 5 0}$ & $2.50^{\mathrm{A}}$ & $21.30^{\mathrm{A}}$ & $36.40^{\mathrm{A}}$ & $52.80^{\mathrm{A}}$ & $4.90^{\mathrm{A}}$ & $1.20^{\mathrm{A}}$ & $1.40^{\mathrm{A}}$ & $6.30^{\mathrm{A}}$ & $5.20^{\mathrm{A}}$ \\
$\mathbf{2 1 0}$ & $2.50^{\mathrm{A}}$ & $21.30^{\mathrm{A}}$ & $36.40^{\mathrm{A}}$ & $52.90^{\mathrm{A}}$ & $4.90^{\mathrm{A}}$ & $1.20^{\mathrm{A}}$ & $1.40^{\mathrm{A}}$ & $6.35^{\mathrm{A}}$ & $5.22^{\mathrm{A}}$ \\
\hline
\end{tabular}

Values followed by the same letter in a column are not significantly different $P \leq 0.05$

*See abstract and materials and methods

\section{Somatic mutation and recombination Tests (SMART) tumor body spots in Drosophila}

The sensitivity of wts tumor suppressor gene for the mutagenic potentialities of Mitomycin C (MMC). In cross, wts females (wts/TM3 Sb) were crossed to wild type (OR) males. However, F1 larvae (48-56 hour old) were treated with the MMC $(20 \mu \mathrm{g} / \mathrm{ml}$ for 24 hour $)$, the data of induced tumors, in addition, to concurrent negative control, are shown in Table (5). The frequencies and distribution of spontaneous and induced tumors after treatment with MMC in both crosses are shown in Table (5). The frequencies of spontaneous tumors in both of negative controls was very low, thirteen small tumors were scored among 310 flies with an average of 0.042 tumor/fly. Meanwhile, After MMC treatment of $\mathrm{F} 1$ larvae, the frequency of induced tumors was highly significant increased, whereas, 288 induced tumors were obtained among 230 flies with a frequency of 1.25 tumor/fly. These tumors were found on all body parts and most of them were undifferentiated large tumors. In DOP $(30 \mu \mathrm{g} / \mathrm{ml})$ and DBP $(30 \mu \mathrm{g} / \mathrm{ml})$ treatments 158 tumors and 135 were scored, respectively. The overall average of induced tumor was 1.5 and 1.4 tumor/fly, (Table 5). However, DOB and DBP treatments were more potent to increase the tumor induction rate in this assay than negative control as illustrated in (Fig. 1).

In vitro assay for cytotoxic activity human cell lines (neutral red assay)

The effects of five different concentrations $(0.5$, $1,5,10$ and $20 \mu \mathrm{g} / \mathrm{ml}$ ) of the two phthalate compounds; Di-butyl phthalate (DBP) and di-octyl phthalate (DOP) on the proliferation of liver cancer cells in comparison to a positive control Doxorubicin $\mathrm{HCL}(3 \mu \mathrm{g} / \mathrm{ml})$ were determined using the neu- tral red cytotoxic assay. In general, the cell viability was decreased gradually as the concentration of the tested phthalates increased (Table 6). The cytotoxicity and cell viability of di-octyl phthalate (DOP) and di-butyl phthalate (DBP ) with the concentrations $(0.5,1,5,10$ and $20 \mu \mathrm{g} / \mathrm{ml})$ and a positive control $3 \mu \mathrm{g} / \mathrm{ml}$ were evaluated in vitro against human liver cell lines (hepatoma cells HepG2). The viability of positive control was $62.85 \%$, and the viability of HepG2 was reduced as the concentration increased of the tested phthalates, but the reduction was non-significant in $0.5 \mu \mathrm{g} / \mathrm{ml}$. The significant reduction in the viability was observed in 1 and $5 \mu \mathrm{g} / \mathrm{ml}$, moreover, highly significant in 10 and $20 \mu \mathrm{g} / \mathrm{ml}$. The Dose inducing $50 \%$ cell growth inhibition (IC50) against hepatoma cell line cells (HepG2) are presented in Table (6).

Results indicated that the use of phthalates may cause potential health risks to human beings Chen et al (2014).

Boekelheide et al (2009) concluded that DBP inhibited proliferation, because they exposed somatic cells in the fetal rat testis with DBP, and the results decreased proliferation, rather than increased apoptosis. DBP may cause genetic defects in male gametes, which may deteriorate sperm quality of male offspring, and delayed sexual maturation of female offspring (Dobrzyńska et al 2011).

Wo'jtowicz et al (2017) demonstrated that DBP- increased ROS production at a concentration of $10 \mathrm{~nm}$, while it activated LDH activities at $1 \mu \mathrm{M}$ and apoptosis (programmed cell death). Moreover, cytotoxic effect (decreased cell viability) was observed. And found the toxicity in rat embryonic midbrain and mesencephalic neurospheres. Abdel-Ghani et al (2014) observed the decreases in fertility of male and female rats, will increase mortality rate with DNA damage. DBP has hepatotoxicity effect, increased of GOT and GPT activity 
Table 5. Frequencies of induced tumor in trans-heterozygous (wts/+) after larvae feeding treatments with concentrations of DOP (di-octyl phthalate) and DBP (Di-butyl phthalate) comparing with the MMC as a positive control and negative control

\begin{tabular}{|c|c|c|c|c|c|}
\hline Treatments & $\begin{array}{l}\text { Total No. of } \\
\text { fly scored }\end{array}$ & $\begin{array}{l}\text { No. of fly } \\
\text { scored with } \\
\text { tumor }\end{array}$ & $\begin{array}{l}\text { No. of tumor } \\
\text { scored }\end{array}$ & $\begin{array}{c}\text { Tumor } \\
\text { induction }\end{array}$ & $\begin{array}{c}\text { Frequency (No. } \\
\text { of Tumor/fly) }\end{array}$ \\
\hline Negative control & 310 & 12 & 13 & 1.1 & 0.042 \\
\hline & 230 & 151 & 288 & 1.9 & 1.25 \\
\hline $\begin{array}{c}\text { DOB } \\
30 \mu \mathrm{g} / \mathrm{ml}\end{array}$ & 250 & 102 & 158 & 1.5 & $0.63^{*}$ \\
\hline $\begin{array}{c}\text { DBP } \\
30 \mu \mathrm{g} / \mathrm{ml} \\
\end{array}$ & 271 & 99 & 135 & 1.4 & $0.5^{*}$ \\
\hline
\end{tabular}

* significant difference from the negative control at $P<0.05$ using Mann, Whitney and Wilcoxon nonparametric $U$ test. Frequency $($ No. of Tumor/fly) $=$ Number of tumors/Total number of tested flies .

Tumor induction $=$ Number of tumors $/$ Number of tumor flies .

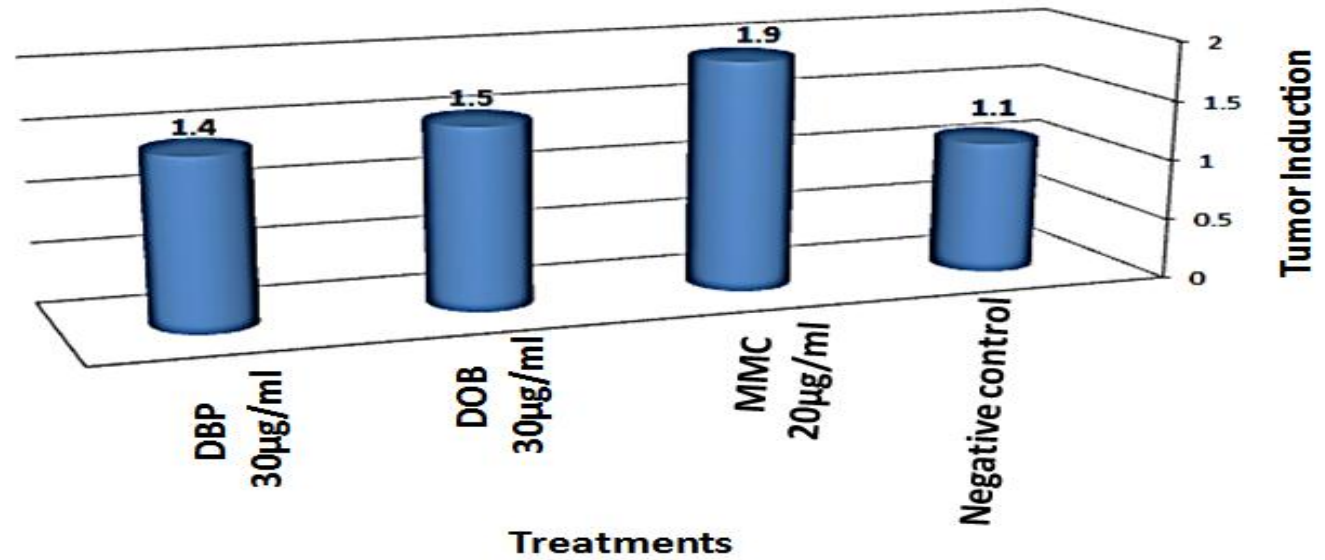

Fig. 1. Diagram represents the tumor induction of spontaneous and induced warts epithelial tumors in $+/ w t s$ flies after treatments with mitomycin C (MMC), DOB and DBP.

Table 6. The cell viability percentage and IC50 of liver cancer human cell lines tested by DOB and DBP compared with Positive control using neutral red cytotoxicity assay

\begin{tabular}{|c|c|c|c|c|}
\hline \multirow{2}{*}{ Human cell line } & Concentration & \multicolumn{2}{|c|}{ Viability \% } & Positive control \\
\cline { 3 - 4 } & $(\boldsymbol{\mu g} / \mathrm{ml})$ & DOB & DBP & $(\mathbf{3} \mathbf{~ g / m l})$ \\
\hline & $0.5 \mu \mathrm{l} / \mathrm{ml}$ & 85.46 & 92.7 & \\
Liver cancer & $1 \mu \mathrm{l} / \mathrm{ml}$ & $55.9^{*}$ & $65.5^{\star}$ & \\
(Hep G2) & $5 \mu \mathrm{l} / \mathrm{ml}$ & $51.98^{\star}$ & $46.6^{\star *}$ & \multirow{2}{*}{62.85} \\
& $10 \mu \mathrm{l} / \mathrm{ml}$ & $31.9^{\star *}$ & $39.5^{\star *}$ & \\
\hline IC50 & $20 \mu \mathrm{l} / \mathrm{ml}$ & $13.8^{\star *}$ & $21.4^{\star *}$ & \\
\hline & & 4.376 & 3.076 & \\
\hline
\end{tabular}

* and ${ }^{* *}$ significant and highly significant difference from the negative control at $P<0.05$ using one-way analysis of variance (ANOVA). 

under direct sunlight

was measurement. Moreover, embryonic, developmental, reproductive toxicity (Chen et al 2014) and potential carcinogenicity was reported. The results agree with $\mathrm{Kim}$ et al (2002), they suggest that DBP and DOP induced developmental toxicity in rat embryonic limb bud cells. The IC50 values of DBP for cytotoxicity in neutral red assay was $25.54 \mu \mathrm{g} / \mathrm{ml}$ and cell differentiation was $21.21 \mu \mathrm{g} / \mathrm{ml}$. The treatment rats with DOP at two to four weeks increased liver replicative DNA synthesis and liver function enzymes were observed (Smith et al 2000).

\section{CONCLUSIONS}

The effect of sunlight exposure on chemicals release into PET- bottled water and the potential hazard of water extracts were investigated using in vitro assay for cytotoxic activity human cell lines. The migration of aldehydes, phthalates and $\mathrm{Sb}$ into water increased with exposure of sunlight especially after $30^{\text {th }}$ day of exposure. Generally, hazardous and undesirable risks could happen due to prolonged photo-degradation and leaching of some carcinogenic chemical compounds from the plastic materials of the bottles. Therefore, this study recommended that PET- bottled water should be only once used and stored in a cool, dry places in the absence of sunlight to avoid health hazards from chemical contamination.

\section{REFERENCES}

Abdul-Ghani, S., Abdul-ghani, R., Qazzaz, M. and Abdeen, Z. 2014. THE effect of di-butyl phthalate (DBP) and di (2-ethylhexyl) phthalates (DEHP) on female rat fertility. International J. of Pharmaceutical Sci. Researches, 5(5), 1671-1681.

Azra, R.S., Marijana, A., Dura, V. and Vera, L. 2012. Deter6mination of carbonyl compounds (acetaldehyde and formaldehyde) in polyethylene terephthalate containers designated for water conservation. Chemical Industry and Chemical Engineering Quarterly, 18(2), 155161.

Batch, C., Dauchy, X., Chagnon, M.C. and Etienne, S. 2012. Chemical compounds and toxicological assessments of drinking water stored in polyethylene terephthalate (PET) bottles. A source of controversy reviewed. Water Research, 46, 571-583.
Boekelheide, K., Kleymenova, E., Liu, K., Swanson, C. and Gaido, K. 2009. Dosedependent effects on cell proliferation, seminiferous tubules, and male germ cells in the fetal rat testis following exposure to di (n-butyl) phthalate. Microscopy Res Tech, 72(8), 629638.

Borenfreund, E. and Puerner, J.A. 1984. A simple quantitative procedure using monolayer cultures for cytotoxicity assays (HTD/NR90). J. Tissue. Cult. Methods, 9, 7-9.

Carneado, S., Nataren, H., Sanchez, J.F. and Sahuquillo, A. 2015. Migration of antimony from polyethylene terephthalate used in mineral water bottles. Food Chemistry, 166, 544-550.

Chen, X., Xu, S., Tan, T., Lee, S.T., Lee, F.W., Liang, S.J., Cheng, S.H. and Ho, K.C. 2014. Toxicity and estrogenic endocrine disrupting activity of phthalates and their mixtures. Int. J. Environ. Res. Public Health, 11, 3156-3168.

Dobrzyńska, M.M., Tyrkiel, E.J. and Pachocki, K.A. 2011. Developmental toxicity in mice following paternal exposure to Di-N-butylphthalate (DBP). Biomed. Environ. Sci., 24(5), 569-578.

Dogra, R.K.S., Khanna, S., Nagale, S.L., Shukla, L.J., Srivastava, S.N., Bhatnagar, M.C., Gupta, P.K. and Shanker, R. 1985. Effect of dioctyl phthalate on immune system of rat. Indian $\mathbf{J}$. of Experimental Biology. 23(6), 315-319.

Fotakis, G. and Timbrell, J. 2006. In vitro cytotoxicity assays: comparison of LDH, neutral red, MTT and protein assay in hepatoma cell lines following exposure to cadmium chloride. Toxicol. Lett, 160, 171-177.

Fujii, J., Luchi, Y., Matsuki, S. and Ishii, T. 2003. Cooperative function of antioxidant and redox systems against oxidative stress in male reproductive tissue. Asian. J. Androl, 5, 231-242.

Hansen, M. B., Nielsen, S.E. and Berg, K. 1989. Re-examination and further development of a precise and rapid dye method for measuring cell growth/cell kill. J. Immunol. Meth, 119, 203-210.

Huang, Y., Li, J. and Garcia, J.M. 2014. Phthalate levels in cord blood are associated with preterm delivery and fetal growth parameters in Chinese women. Plos. One, 9(2), e87430.

ILSI, 2000. International Life Science Institute. Packaging Material: Polyethylene Terephthalate (PET) for Food Packaging Applications. Europe, Belgium. $1 \mathbf{p}$. 
Kavlock, R., Barr, D. and Boekelheide, K. 2006. NTP- CERHR expert panel update on the reproductive and developmental toxicity of di (2ethylhexyl) phthalate. Reprod. Toxicol, 22, 291-399.

Kim, S.H., Kim, S.S., Kwon, O., Sohn, K.H., Kwack, S. Jun., Choi, Y.W., Han, S.Y., Lee, M. K. and Kui, L.P. 2002. Effects of Dibutyl phthalate and Monobutyl phthalate on Cytotoxicity and Differentiation in Cultured Rat Embryonic Limb bud Cells. Protection by Antioxidants J. of Toxicology and Environmental Health, 65, 5-10.

Kleinsasser, N.H. 2000. Phthalates Demonstrate Genotoxicity on Human Mucosa of the Upper Aerodigestive Tract. Environmental and Molecular Mutagenesis, 35, 9 - 12.

Lindsley, D.L. and Zimm, G.G. 1992. The Genome of Drosophila melanogaster. Academic Press, San Diego, California. USA, 1133 p.

Matthews, T.G. and Howell, T.C. 1981. Water Analysis Hand Book. J. of the Air Pollution Control Association, 31(11), 1181-1184.

Muhamad, S.G., Esmail, L.S. and Hasan, S.H. 2011. Effect of storage temperature and sunlight exposure on the physicochemical properties of bottled water in Kurdistan region-Iraq. J. Appl. Sci. Environ. Manage, 15(1), 147 - 154.

Nepomuceno, J.C. 2015. Using the Drosophila melanogaster to assessment carcinogenic agents through the test for detection of epithelial tumor tlones (Warts). Adv. Tech. Biol. Med, 3, (3), 2-8.
Shotyk, W. and Krachler, M. 2007. Contamination of bottled waters with antimony leaching from polyethylene terephthalate (PET) increases upon storage. Environ. Sci. Technol, 41, 1560-1563.

Sidorov, R.A., Ugnivenko, E.G., Khovanova, E.M. and Belitsky, G.A. 2001. Induction of tumor clones in $D$. melanogaster wts/+ heterozygotes with chemical carcinogens. Mutation Research, 498, 181-191.

Smith, J.H., Isenberg, J.S., Pugh, G.J., Kamendulis, L.M., Ackley, D., Lington, A.W. and Klaunig, J.E. 2000. Comparative in vivo hepatic effects of di-isononyl phthalate (DINP) and related $\mathrm{C} 7-\mathrm{C} 11$ dialkyl phthalates on gap junctional intercellular communication (GJIC), peroxisomal beta-oxidation (PBOX), and DNA synthesis in rat and mouse liver. Toxicological Sci., 54(2), 312-321.

Tienpont, B., David, F., Dewulf, E. and Sandra, P. 2005. Pitfalls and solutions for the trace determination of phthalates in Water Samples. Chromatographia, 61(7), 365-370.

Williams, D.T. and Blanchfield, B.J. 1975. The retention, distribution, excretion, and metabolism of dibutyl phthalate in the rat. J. Agric. Food. Chem, 23, 854-858.

Wo'jtowicz, A.K., Konrad, A.S., Agnieszka, W. and Małgorzata, K. 2017. Dibutyl Phthalate (DBP)-Induced Apoptosis and Neuro toxicity are Mediated via the Aryl Hydrocarbon Receptor (AhR) but not by Estrogen Receptor Alpha (ERa), Estrogen Receptor Beta (ERb), or Peroxisome Proliferator-Activated Receptor Gamma (PPARc) in Mouse Cortical Neurons. Neurotox Res. 31, 77-89. 


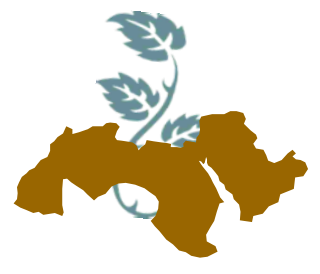

التأثير الوراثى للمركبات المهاجرة من مياه الثرب الطبيعية المعبأة والمخزنة تحت

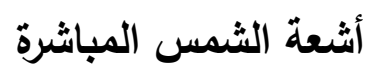

[140]

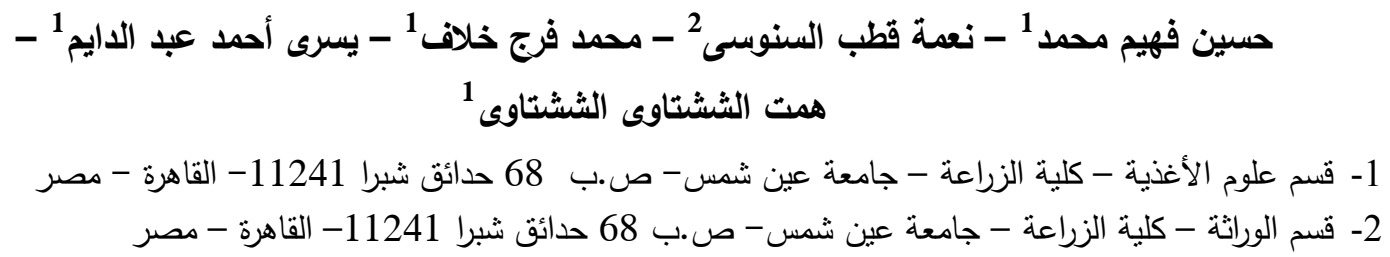

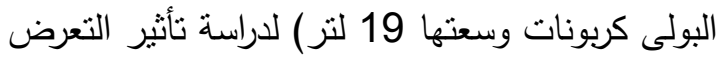

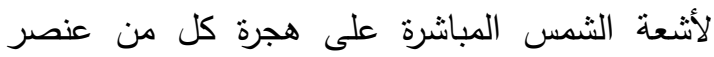
الأنتيمون وكنلك مجموعة مركبات الفينالات. وأجريت

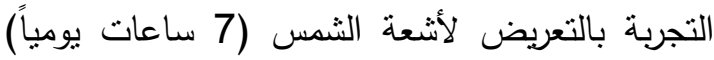

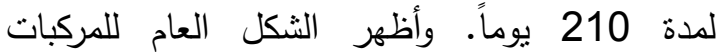

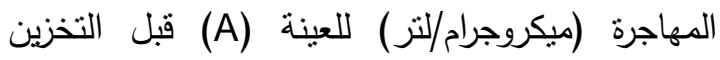

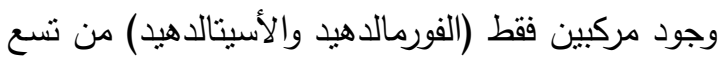

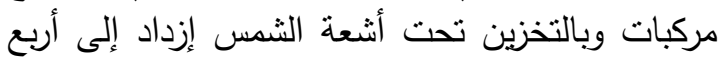

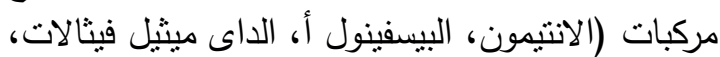
الداى إيثيل فيثالات). حتى اليوم الثنالثون ثم لم يتأثر

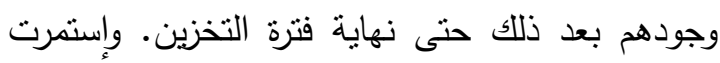

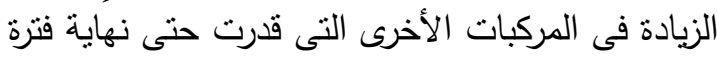

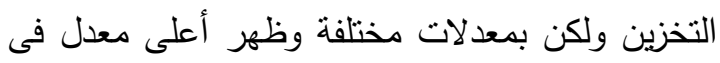
حالة الفورمالدهيد حيث كان بزيادة مقدارها (222

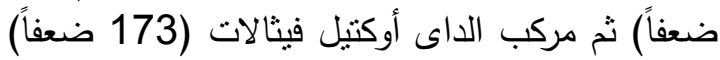

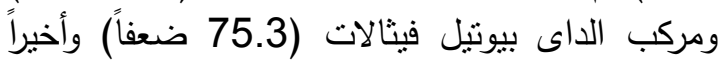

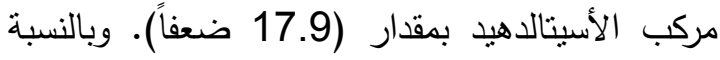

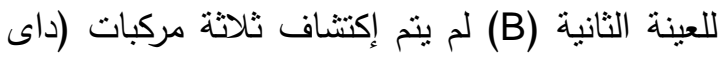

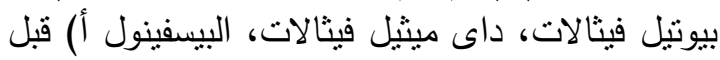

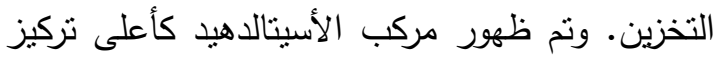

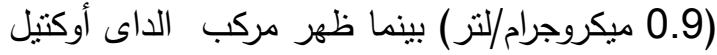
فيثالات كأقل نركيز (0.007 ميكروجرام/لتنر) وظهر قبل التخزين أربع مركبات فقط هما (الأنتيمون، الداى
الكلمات الدالة: عبوات البولى إينلين ثيرفيثالات، المياه

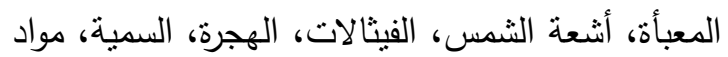

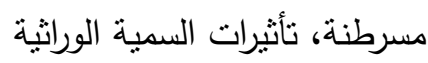

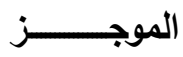

تعتبر مياه الثرب الطبيعية واحدة من أهم مسببات

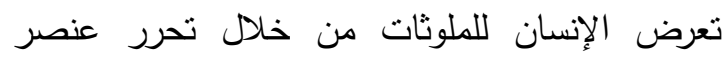

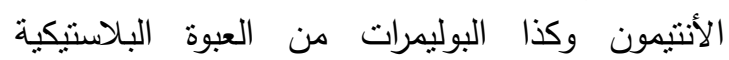
المصنعة من البولى إيثيلين تيرفيثالات (PET). ويهدف هذا البحث إلى دراسة تأثير أثنعة الشمس على الثى الثى

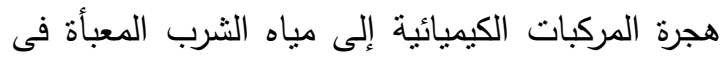

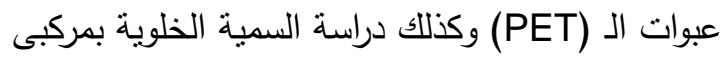
الداى بيوتيل فيثالات (DBP) والداى أوكتيل فيثنالات

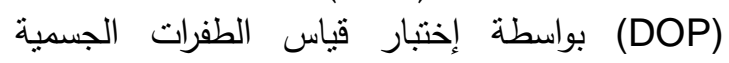
والعبور الوراثى (SMART) فى حشرة الدروسوفيلا. وتمت الدراسة على أربع عينات عشوائية من مياه

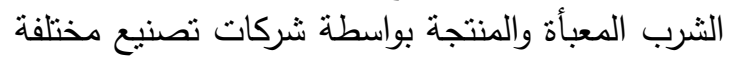

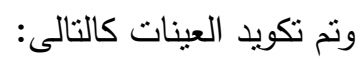

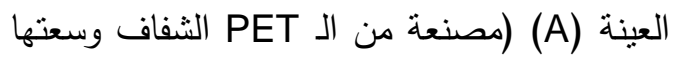

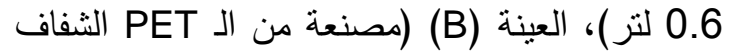

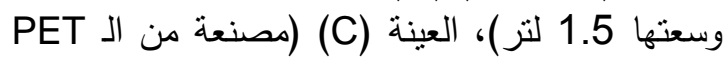

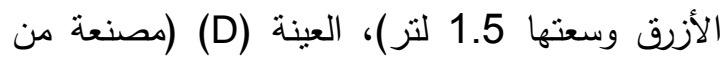


المسرطنة؛ مثل خلايا سرطان الكبد (HepG2)، خلايا سرطان القولون (HCT-116) وتقييم السمية الخلوية بإختبار السمية الخلوية الحمراء المعتدلة. علاوة على على ذللك، تم تقييم القدرة على إحداث التسرطن بإستخدام

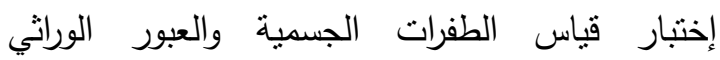
(SMART) تكوين الأورام وزيادة معدلها مقارنة بالعينة المرجعية (الكنترول)، كما حدث خفض في حيونة

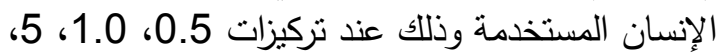
10 و 20 ميكروجرام/مل ولم يظهر أي تأثثر علير علي

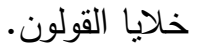

أوكتيل فيثالات، الفورمالدهيد، الأسيتالدهيد). وكان أقل تركيز هو لمركب الداى أوكتيل فيثالات ( 0.006 ميكروجرام/لتز) بينما سجل مركب الفورمالدهيد بقيمة

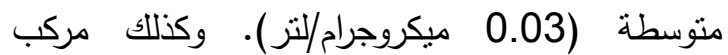

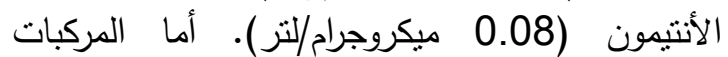
الأخرى التى قدرت وهى (الداى بيوتيل فيثالات، الداى

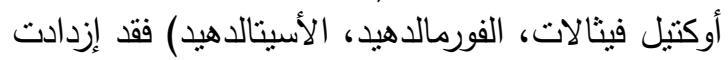

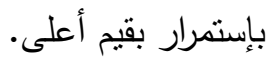

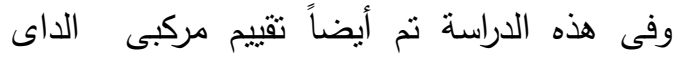
بيونيل فيثالات والداى أوكتيل فيثالات بنتركيز 30 ميكروجرام/مل علي بعض خطوط خلايا الإنسان 
1915

مجلة اتحاد الجامعات العربية

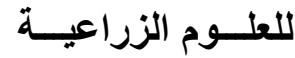

جامعة عين شمس ، الزعاعـة القرة

مجلا(26)، عدد (2C)، عدد خداص ، 1907 - 1916، 2018 